\title{
The formation of modular structures through the prism of architecture in marine areas
}

\author{
Valery Tovbych ${ }^{1}$, Halyna Kravchuk ${ }^{2}$ \\ ${ }^{1}$ Kiev National University of Civil Engineering and Architecture \\ Povitroflotskyi Avenue 31, Kyiv, Ukraine, 03680 \\ tovbych@gmail.com, orcid.org/0000-0002-4794-4944 \\ ${ }^{2}$ National Aviation University \\ Cosmonaut Komarov Avenue 1, Kiev, Ukraine, 03058 \\ kravchuk770@ukr.net, orcid.org/0000-0002-8840-0476
}

Received 05.06.2019, accepted after revision 06.06.2019

https://doi.org/10.31493/uwt1909.1903

\begin{abstract}
The causes of actualization of the problem of water urbanism are shown. The key suggestions for possible formation of floating structures are considered, the international experience of such objects design are analyzed. The question of the formation of modular structures are based on the methods of geometric modeling. The correct and semi-regular polyhedra are analyzed as the most streamlined figures from the point of view of utilitarian, stability, and buoyancy. Because of such figures form the largest internal usable volume with a minimum surface area and have a regular symmetrical structure.

The basic properties of continuous filling of three-dimensional space on the basis of modular design of convex polyhedrons of spherical type are revealed. An important prerequisite is the unification of the modules of mutual harmonization of system elements on the basis of multiplicity. The advantages of modular design and the possibility of forming the floating structures are analyzed. It is proposed to solve the modular structure of the three-dimensional cross-core structural system (the spatial framework solves not only the functionalutilitarian problem of overlapping the space, but is the formative structure of the whole building).

Based on the generalized project experience, new approaches and state-of-the-art engineering and technological solutions have been identified to unlock the potential of marine ecosystems for future development.

The main aspects of the formation of modular structures in the marine areas are highlighted, in particular, the following:
\end{abstract}

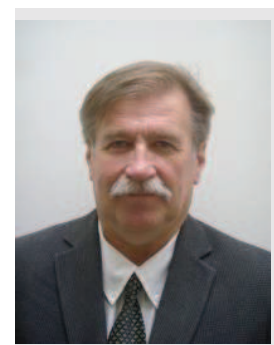

\section{Valery Tovbych}

Head of the Department

of Information Technologies

in Architecture

ScD Architecture, Prof.

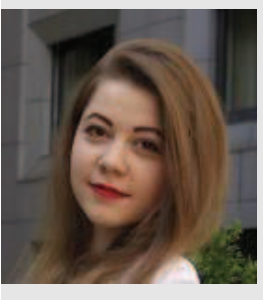

Halyna Kravchuk

Master of Architecture

Department

- formation of floating structures is analyzed on the basis of geometric modeling methods;

- a three-dimensional cross-core structural system based on regular polyhedra is proposed;

- the structural features of the formation of floating structures and the outlined prospects of water urbanism are distinguished.

Keywords: shaping, geometric modeling, block-modular structures, cross-core structural systems, combinatorics.

\section{THE PROBLEM STATEMENT}

The technogenic development of cities and its mechanization, the rapid growth of agglomerations, the ever-increasing harmful emission into the atmosphere and the spontaneous use of natural resources lead to the de- 
struction of the integrity of the environment. In this case, undesirable processes occurring in the environment have a negative impact on human health by creating unsuitable conditions for their life [1].

In general, the 21 st century is characterized with the rapid exacerbation of environmental catastrophes. The emergence and increase of the greenhouse effect have caused climate change, as a consequence of global warming and rising of ocean level.

According to the forecasts of the Intergovernmental Panel on Climate Evolution, about 25 million inhabitants of our planet may be in the flood zone $[2,3]$. The modern world is characterized by an extremely active pace of development and introduction of the latest technologies in all spheres of life. Due to the modern development of technologies and the emergence of new materials, engineering capabilities have come close to successful implementation of ambitious projects in the most extreme conditions, including on the water.

Despite the breadth of coverage of the problem of molding modular structures, much of the aspect remains undisclosed.

\section{THE ANALYSIS OF PREVIOUS STUDIES}

With the development and improvement of technological progress, relatively new trends and concepts of dynamic architecture capable of transformation are forming. Mobile architecture and futuristic design are gaining urgency in an era of social urbanization and scarcity of free territories.

These trends advocate the rational use of land and water space, seeking the application of new technological capabilities, modularity and variability.

The new progressive direction in construction and architecture is the formation of objects in relation to the aquatic environment.

Conceptual developments of architectural objects are handled by the studio of A.A. Asadova, architects V.I. Plotkin, I. Ovchinnikov. The study of individual aspects of modularity and architectural shaping are characteristic of creativity. Le Corbusier, N.A. Saprinini, Yu.L. Sherman, A.A. Gaiduchen.

Research on underwater urban studies questions and answers of the present are considered in the work of Ruban L. [3].

In Western Europe, such as France, Italy, the Netherlands, the United Kingdom, as well as Canada and the UAE, the typology of objects on the surface of water is expanding today $[2,4,5]$.

The range of materials used in the construction of floating objects is gradually expanding, which testifies to the growing tendencies of this type of real estate over traditional aboveground objects $[3,5]$.

The most significant advances in maritime architecture belong to the United States. One of the projects of successful realization is housing for workers, which is prefabricated. They are delivered by trucks to the right place and are collected in a few days. The main advantage that can be distinguished in the standardization of the design solution is the copying of the same buildings $[2,4,6]$.

In recent years, the United Arab Emirates has built many amazing objects and masterpieces of architecture, a huge number of artificial islands and skyscrapers, hotels, shopping malls and amusement parks in the sea.

Architect Vincent Callebout developed the concept of a self-sufficient floating city "Lilypad Floating City", with a capacity of up to 50,000 people.

The purpose of the project is to create a harmonious co-existence of man and nature, a project positioned by the author as a "floating ecopolis for climate refugees".

Lilypad is a real amphibian that is a halfwater and half-earth city (Figs.1,2).

The multifunctional and full-fledged infrastructure of the floating city is based on three marinas and ships, three mountains (lilyshaped petals) designed for work, shops and entertainment. The whole complex of landscaping located near the dwelling in the suspended gardens intersects the network of streets and alleys, forming an organic natural contour $[2,4]$. 


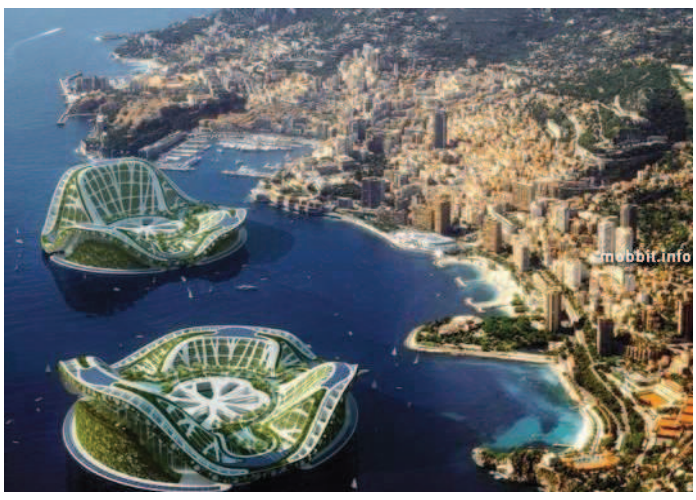

Fig.1. Floating City, architect Vincent Callebaut, Brazil, 2010

Such an island city will use the latest ecotechnologies, such as solar panels, conversion of wind energy, ebb and flow in order to ensure the life quality of its residents.

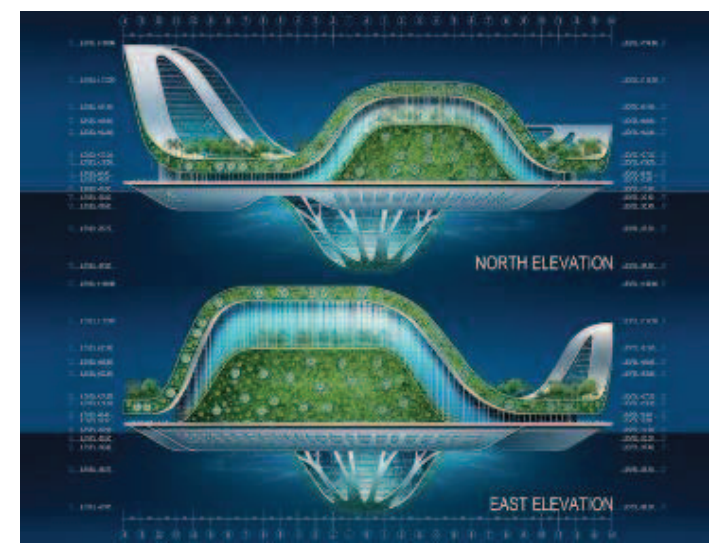

Fig.2. Floating City, architect Vincent Callebaut, Brazil, 2010

In addition, the Lath will clean the atmosphere of carbon dioxide with its titanium dioxide coating.

The construction of the facility involves partial construction of 4,000 apartments with original infrastructure [4].

The liner will be of high strength polyester fiber coated with titanium dioxide. Mechanisms and technical solutions for using wind energy, tides and even biomass energy will also be applied. Water purification by the method of reverse osmosis successfully tested on aircraft carriers and a number of technical solutions that will ensure self-sufficient, autonomous functioning of the city [2].
For China, that is a home to about 1.4 billion people, overpopulation is a serious problem. Therefore, a floating ocean metropolis project developed by China Communications Construction Company (CCCC-FHDI) in collaboration with the AT Design Office is economically viable and promising $[6,9,10]$.

Conceptual design designed for long-term autonomous ocean life. It is a structure of combined floating hexagonal modules with a total area of $10.36 \mathrm{~km}^{2}[8,9]$.

Constructed as different geometric shapes, the sections, the largest hexagonal modules measuring 150 meters by 30 , can be based on an equilateral triangle and a pentagon that divides the water surface .

Designed to be a completely self-sufficient and with zero carbon emissions, the floating city includes farms and waste management systems (Fig.3).

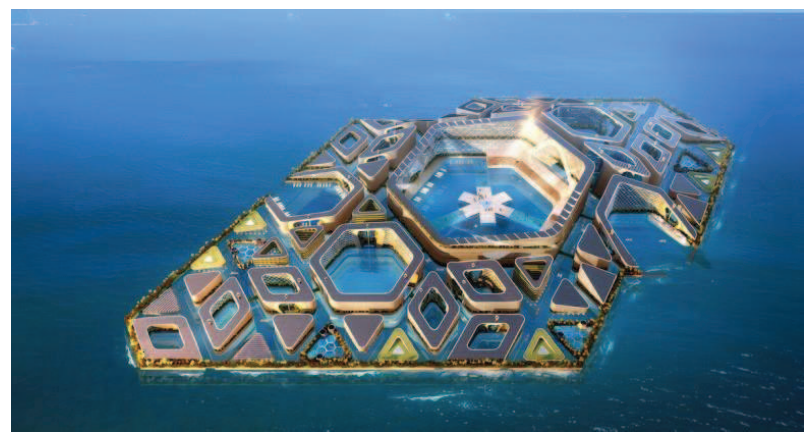

Fig.3. City Water Project, China Communications Construction Company (CCCC-FHDI) \& AT Design Office, China, 2014

To move between the different structures of the submarine and surface parts of the city, the project's creators plan to use a line-wide network of submarines and submarines. It is also planned to build highways for land transport by electric traction.

The project envisages residential, commercial and recreational areas; a large area of land will be allocated to green spaces, which are also located at different levels.

Yes, a public green belt on the water surface can provide public space for sports and recreation in the fresh air. The underwater green belt can be used for recreational tours. The island has vertical gardens and animal 
farms that provide residents with all the food they need.

Many marine structures have been constructed to date, and there are a number of design solutions for the formation of waterrelated objects [6].

However, the examples and technology provided are not enough. The issues of engineering systems as well as design technologies, methods of structural systems and features of process planning remain unresolved.

\section{MAIN RESEARCH}

Modular homes are a new modern vision of what could be functional and comfortable architecture for today. Mobile modular house is a modern facility which has a number of advantages:

- high comfort;

- durability and environmental friendliness;

- the cost of maintenance and operation;

- operational production, delivery and assembly;

- compactness and mobility [13, 21-23].

Modularity is closely related to the possibility of transformation, which can manifest itself within both a single structure and composite solutions of multi-component structures [1314].

The transformation of the exterior structure of the building allows for open interaction with the environment. There may also be a transformation of planned interior space solutions by means of displacement, partitioning depending on functional zoning. Therefore, transformation, by virtue of its mobile structure, can modify an object in different ways, which allows the formation of different structures on the basis of one module [7].

The term "modularity" is considered as a conventional unit of form used to coordinate parts of an object and the whole complex [1519].

Modularity maximizes object output while delivering high variability in planning decisions.

In forming the structure, the most important element is the shape of the module, which is due to the purpose of functional filling, as well as the rational use of physical and mechanical properties of structures.

The form should provide a number of specific properties for full functioning in the marine areas, such as:

- volume;

- spaciousness;

- ability to move and be transformed;

- geometric modeling;

- weight;

- massiveness;

- density.

The dense filling of the space during the formation of modular structures is realized on the basis of geometric modeling, where the single element is the figure of a regular polyhedron, as the most streamlined and stable figure, which with its parallel displacements relative to the axes forms multilayered structures.

The solid filling of the three-dimensional space is replaced by the modules obtained by modifying the original convex polyhedra of spherical type. After all, such polyhedra form the largest internal usable volume at a minimum surface area, while having a regular symmetrical structure.

You can find new fillings of space by arranging the arrangement of Ahmed bodies around a common edge in which adjacent bodies have common incongruent boundaries. All polyhedral angles at vertices are congruent, where the dihedral angles of these polyhedra on the common edge should be a full angle $\left(360^{\circ}\right)$ [9-10].

The most appropriate figures among convex polyhedra satisfying this condition are paralleleloids (Fig.4).

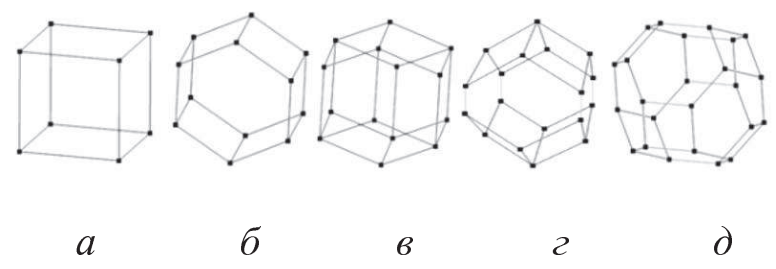

Fig.4. Types of parallelohedra: $a$ - cube, $\sigma$ - sixangle prism, $b$ - rhombododecahedron, $d-$ elongated dodecahedron, $\partial$ - truncated octahedron 
There are exactly five topological types of paralleleloids in three-dimensional space:

- cube;

- hexagonal prism;

- rhombododecahedron;

- elongated dodecahedron;

- truncated octahedron.

An important condition for the formation of structures is the unification of single modules a single modular system of mutual coordination of the size of structures and their elements and structures, as well as their equipment based on the multiplicity of the module [9-10].

Given the specific conditions of the location of such objects, it is advisable to ensure the structural strength of both one element and the structure as a whole (Figs. 5).

The use of the light metal is a key constructive solution of frame structures. The carrier element for the solution of the modular structure is the spatial cross-rod structural system. It is formed from steel tubes and connected pivotally. Such systems have the great forming capabilities, allowing to solve almost any space-problems of composition [13-15, 17].

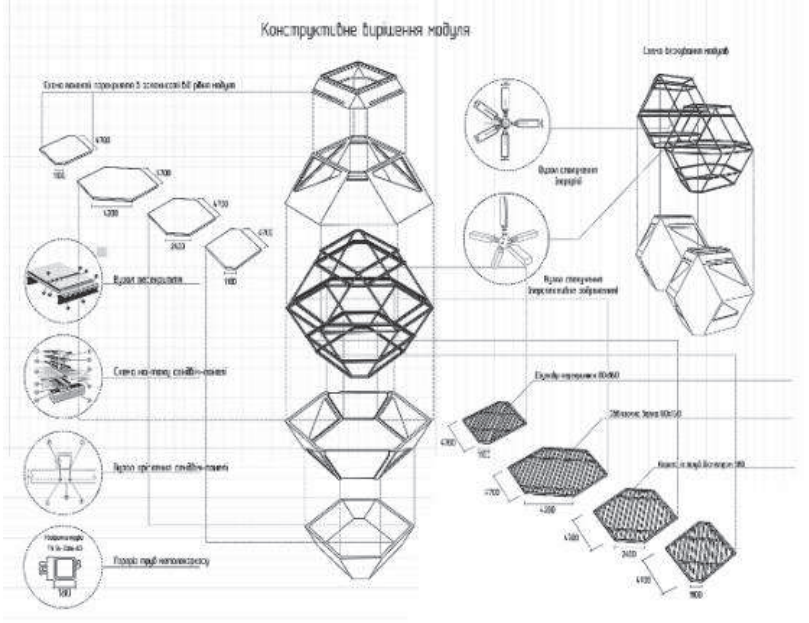

Fig.5. Schematic diagram of a cross-sectional structural structure based on geometric modeling from polyhedra

Assembled from separate tubular multifaceted rods and nodal elements with a single bolted connection, USPK system MARCHI represent regular structures on the basis of the regular polyhedrons providing a single length of the modular rod within the designed struc- ture, which enables the use of engineering methods for the manufacture of structural parts (automated technologies).

An important advantage of the system is the use of special nodal elements of the hemispherical type in accordance with orthogonal and triangular grids, as well as asymmetrical elements under different diameters of bolts compared to the universal spherical polyhedron, which allows to further reduce the metal consumption and complexity of manufacturing the nodal element [13-15].

Considering the features of cross-bar structural systems, a number of features can be distinguished regarding their application [17-22]:

1) ensuring the uniformity of prefabricated elements and technologies for their manufacture, which can be applied at factories using modern automated and robotic systems;

2) possibility of connection of all elements on bolts, without welding and tampering (easily mounted);

3) versatility for use - both for individual low-rise residential, industrial, public and other purpose buildings;

4) the flexibility of frames, as collapsible structures, which can be disassembled and reused, as well as with the change of purpose of buildings (replacement or damage of the module if necessary);

5) providing the spatial nature of the frame structure, in which all elements form longitudinal and transverse frame frames.

\section{CONCLUSIONS}

The main aspects of the formation of modular structures in the marine areas are highlighted, in particular, the following.

1. Formation of floating structures is analyzed on the basis of geometric modeling methods (in the three-dimensional space there are exactly five topological types of parallelohedrons: cube, hexagonal prism, rhombododecahedron, elongated dodecahedron, truncated octahedron, as the most streamlined figures).

2. The advantages of modular design, as well as the possibility of forming floating structures. 
3. A three-dimensional cross-core structural system based on regular polyhedra is proposed.

4. The structural features of the formation of floating structures and the outlined prospects of water urbanism are distinguished.

\section{REFERENCES}

1. Osipov V.M., Kukos M.C., 2014. Konkurentability of urban agglomerations: world tendencies and prospects of formation in Ukraine. Economic innovations, Iss.57, 283296 (in Ukrainian).

2. The French architect came up with the plans of the city for climate refugees, 2008. Access mode

http://realty.newsru.com/article/23Jun2008/lily.

3. Ruban L., 2016. Underwater Urban Studies: Questions and Answers of Modernity. Underwater technology. Industrial and civil engineering. 2016. Iss.03, 54-65. Access mode: http://repositary.knuba.edu.ua/handle/98765432 $1 / 237$ (in Ukrainian).

4. Zavodskov S., 2014. Lilypad floating city in Dubai. Access mode http://uae-dubai.ru/uaeblogs/article/lilypadplavayuschiy-gorod-vdubae (in Russian).

5. Modularity in the architecture of different countries. Access mode http://tver13.ru/stroitelstvo/8131/ (in Russian).

6. The Chinese plan to use the surface of the Earth, covered with water, in 2014, for the construction of future cities. Access mode https://itc.ua/news/kitaytsyi-planiruyutispolzovat-dlya-postroeniya-gorodovbudushhego-poverhnost-zemli-pokryituyuvodoy/ (in Russian).

7. Safonov N.A., Zhusupova AM, Siroshtan D.A. Use of innovative construction methods and their influence on the three-tier of construction production, Iss.4 Access mode https://nauchforum.ru/studconf/tech/4/36113 (in Ukrainian).

8. Ruban L., 2014. Principles of architectural and landscape design of water areas. Technical transactions. Architecture and urban planning Iss.6, 29-40. Access mode file:///C:/Users/ Galyna/Downloads/3-CT-6-2018.pdf.

9. Bonchkovsky R.N.. Filling the space with tetrahedra. Collection of articles on elementary and higher mathematics. Iss.4, 26-40 (in Ukrainian). Access mode http://www.mathnet.ru/links/cc2fdf608dec92f9f e7c3544c54bd2c3/mp562.pdf
10.Filling the space with polyhedral. Access mode http://mat.1sep.ru/view article.php? ID =200900 503 (in Russian).

11.Ekonomov, I.S., 2010. Principles of formation of low-rise living objects on water, 235. Access mode https://www.dissercat.com/content/ printsipy-formirovaniya-maloetazhnykhzhilykh-obektov-na-vode (in Russian).

12.Krivolapova A.V. Modular principle of shaping in architecture. Access mode http://book.uraic.ru/project/conf/txt/005/archvu z26 pril/14/template article-ar=K01-20-k3.htm (in Ukrainian).

13. Chernykh I.Yu., 2010. Steel tubes structures Cross-bridge systems with guaranteed indicators durability, 2005. Access mode https://otherreferats.allbest.ru/construction/0044 3997 0.html (in Russian).

14.Korolev V.P., Chernykh I.Yu., 2001. Calculation of elements and compounds of cross-rod systems for corrosion resistance and durability. Abstract dissertation for a scientific degree Candidate of Technical Sciences, 2005. 35-38 Access mode http://donnasa.ru/publish house/ journals/vestnik/2010/maket_2010-6(86).pdf (in Russian).

15.Mushinsky A.N., Zimin S.S., 2015. Construction of pre-fabricated buildings and structures. Construction of unique buildings and structures, Iss. 4(31) (in Russian).

16.Uniform modular system, unification, typing, standardization, normalization in construction. Access mode https://studfiles.net/preview/ 5303687/page:5/ (in Ukrainian).

17.Korolev V.P., Gibalenko A.N., Chernykh I.Yu., 2000. Nodal connection of steel tubular spatial structures. Bulletin of the Donbass National Academy of Construction and Architecture, Iss. 1(21), 31-32. Access mode http://donnasa.ru/publish house/journals/vestni k/2017/vestnik 2017-3(125).pdf (in Russian).

18.Gorbatenko E., Bratasyuk I., Sharov V., 2015. Mobile structures in coastal hydrotechnics. Second International Conference on Underwater Technology. Underwater Technologies, Iss.01, 23-32.

19.Safonov N.A., Zhusupova A.M., Se-roshtan D.A. The use of innovative construction methods and their impact on the duration of construction production. Technical and mathematical sciences. Student Scientific Forum: Electr. Sat Art. by mat. IV international Stud. scientific-practical conf. Iss. 4 (4) (in Russian). Access mode https://nauchforum.ru/archive/SNF tech/4\%284 \%29.pdf (in Russian). 
20.Technical Encyclopedia. Unique modular system. Access mode http://techtrend.com.ua/ index.php?newsid $=1458$ (in Ukrainian).

21.Ageev M.D., 2003. Autonomous underwater robots: systems and technologies. Institute of Marine Technology Problems. Moscow, Science, 2005, 398 (in Russian). Access mode https://www.studmed.ru/ageev-md-i-dravtonomnye-podvodnye-roboty-sistemy-itehnologii 2f9001c63d2.html

22.Molchanova V., 2018. The methods of homotopic skeletonization of bit-mapped drawings of parts of sea transport. Transfer of Innovative Technologies, Iss.1. Access mode https://cyberleninka.ru/article/n/the-techniqueof-homotopic-skeletonization-of-bit-mappeddrawings-of-parts-of-sea-transport.

\section{Формообразования модульных структур через призму архитектуры на морских акваториях}

\section{Валерий Товбич, Галина Кравчук}

Аннотация. Показаны причины актуализации проблемы водного урбанизма. Рассмотрены основные предложения по возможному формированию плавучих конструкций, проанализирован международный опыт проектирования таких объектов. Вопрос формирования модульных структур основывается на методах геометрического моделирования. Проанализированы правильные и полуправильные многогранники, как наиболее обтекаемые фигуры с позиции утилитарности, устойчивости, плавучести. Поскольку такие фигуры образуют внутренний полезный объем при минимальной площади поверхности и обладают регулярной симметричной структурой.
Выявлены основные свойства непрерывного заполнения трехмерного пространства на основе модульной конструкции выпуклых многогранников сферического типа. Важным условием является унификация модулей взаимного согласования элементов системы на основе кратности. Проанализированы преимущества модульного проектирования и возможности формообразования плавучих структур. Предложено для решения модульной структуры объемно-пространственную перекрестностержневую конструктивную систему (пространственный каркас решает не только функционально-утилитарная задача перекрытия пространства, а есть формообразующей структурой всего сооружения).

Освещены основные аспекты формообразования модульных структур на морских акваториях, в частности:

- проанализировано формообразование плавучих структур на основе методов геометрического моделирования;

- предложено объемно-пространственную перекрестно-стержневую конструктивную систему на основе правильных многоугольников.

- выделены конструктивные особенности формообразования плавучих структур и определение перспектив водной урбанистики.

Ключевые слова: формообразования, геометрическое моделирование, блочно-модульные структуры, перекрестно-стержневые конструктивные системы, комбинаторика 